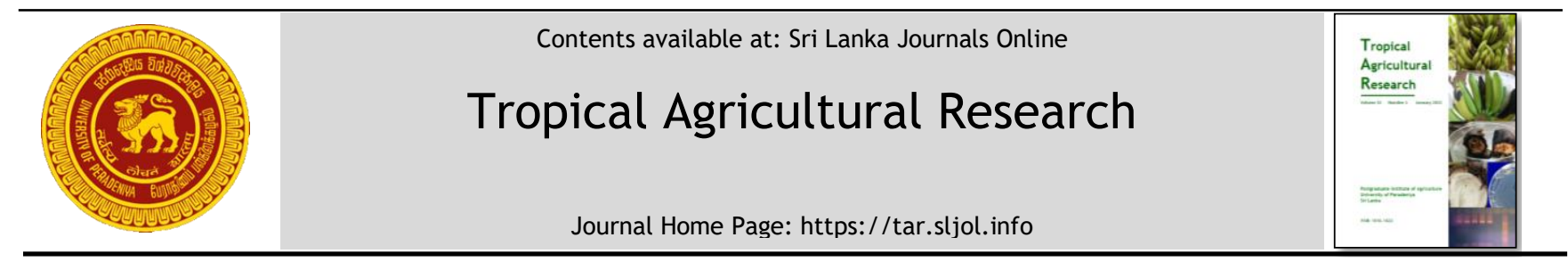

\title{
Incorporating Breadfruit Flour to Prepare High-Quality Cookies with Health Benefits
}

\author{
L.R. Ishera ${ }^{1}$, T. Mahendran ${ }^{1}$ and M.R. Roshana ${ }^{2 *}$ \\ ${ }^{1}$ Department of Agricultural Chemistry, Faculty of Agriculture, Eastern University, Sri Lanka. \\ ${ }^{2}$ Department of Biosystems Technology, Faculty of Technology, South Eastern University of Sri Lanka
}

\section{ARTICLE INFO}

\section{Article history:}

Received: 19 June 2020

Revised version received: 24 October 2020

Accepted: 07 November 2020

Available online: 1 January 2021

\section{Keywords:}

Breadfruit

Composite flour

Cookies

Nutritional quality

Antioxidants

\section{Citation:}

Ishera, L.R., Mahendran, T. and Roshana, M.R. (2021). Incorporating Breadfruit Flour to Prepare High-Quality Cookies with Health Benefits. Tropical Agricultural Research, 32(1): 114-123.

DOI: http://doi.org/10.4038/tar.v32i1.8447

Ishera, L.R.

https://orcid.org/0000-0002-3356-465X

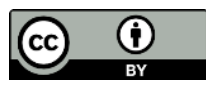

ABSTRACT

Cookies are popular, fast and convenient snacks generally consumed by people of all ages. This study was carried out to determine the effects of incorporating breadfruit flour as a recipe ingredient of cookies on physical, nutritional and sensory properties of the cookies. Good quality, mature breadfruits were washed, peeled and cut into slices of $1-\mathrm{mm}$ thickness. The slices were oven dried at $105{ }^{\circ} \mathrm{C}$ for 3 hours. The dried chips were ground into flour and stored in an airtight container at $4{ }^{\circ} \mathrm{C}$. Different composite blends of wheat: breadfruit flour (100:0, $80: 20,60: 40,40: 60,20: 80$ and 0:100 percent ratios) were used as flour in recipe of preparing the cookies. The cookies made from different composite blends of flour were analysed for physical, nutritional and sensory qualities. The physical characteristics such as diameter, spread ratio, volume and breaking strength of the cookies decreased while the thickness increased, significantly $(\mathrm{p}<0.05)$ with increasing breadfruit flour from 0 to $100 \%$. The moisture, ash, fibre, total carbohydrate, total phenolic content and antioxidant activity of the cookies increased while fat and protein content decreased with increasing breadfruit flour from 0 to $100 \%$. According to Tukey's test, the $40 \%$ breadfruit flour added cookies had the highest mean scores compared with other treatments and its overall acceptability which was not significantly different ( $p>0.05)$ from those made with $100 \%$ wheat flour. Therefore, cookies made with the blend wheat: breadfruit flour at 60:40 percent ratio were highly acceptable based on the physical, nutritional and sensory qualities. These cookies were rich in fibre, minerals, carbohydrates, total phenolic content, antioxidant activity and low in fat content compared with the ones produced using 100\% wheat flour. The use of wheat-breadfruit composite flour in preparing cookies would be a value addition while it promotes the diversification of utilization of breadfruit in Sri Lanka and globally.

*Corresponding author: mrroshana30@gmail.com 


\section{INTRODUCTION}

Cookies are a bakery product and a snack food devoured by many people in the world and provides a good source of nutrients (Arshad et al., 2007). Cookies are popular because of the low manufacturing cost, high stability, long shelf-life and ability to carry a high amount of nutrients (Honda and Jood, 2005). The principle ingredients of cookies are flour, fat, sugar, water, milk, salt, flavouring agents and aerating agents (Suriya et al., 2017). High contents of fat and sugar and low contents of protein, fibre, vitamins and minerals lead to consider many cookie recipies as unhealthy snacks.

Fat provides sensory attributes such as texture, mouthfeel and flavour to the cookies. Particularly the soft-type cookies contain relatively larger contents of fat. According to the Dietary Guidelines, fat should be consumed in moderate amount (Drewnowski et al., 1998). Several studies have been carried out to improve the quality and consumer acceptability of cookies to maximize the fibre, protein, vitamin and mineral content while reducing the fat content (Ebere et al., 2015; Emelike et al., 2015; Kiin-Kabari and Giami, 2015). A study used cashew apple residue in a cookie recipe as a source of fibre (Ebere et al., 2015). Studies have been conducted to enrich cookies with plant protein sources using Moringa leaf powder (Emelike et al., 2015) and Bambara groundnut protein concentrate (Kiin-Kabari and Giami, 2015) etc. Several fat replacers have been targeted for developing low-fat snacks. At present animal originated fat replacers are being used very often in the preparation of cookies, which may deter vegetarians. Further, preparation of cookies with low fat content will improve consumer acceptance and would raise the demand for them.

Breadfruit contains an average of $0.31 \%$ fat, $1.34 \%$ protein, $27.8 \%$ carbohydrate, $1.5 \%$ fibre and $1.23 \%$ ash (Wang et al., 2011) while breadfruit flour has been reported to contain about $76.7 \%$ carbohydrate, $17.1 \%$ protein, $11.1 \%$ fat, $3.0 \%$ ash and $0.1 \%$ crude fibre (Akubor et al., 2000). Breadfruit consists of several minerals such as copper, magnesium, phosphorous, potassium, calcium, cobalt, iron, and manganese in variable levels based on growth location and cultivar (Ragone, 2006). The fruit does not contain gluten proteins that are harmful to patients with celiac disease and can also be a potential ingredient for use of gluten-free products. Very often in the regions where breadfruit grows abundantly, different types of flour are being imported to satisfy food requirement. The use of breadfruit flour to replace usually imported flour such as wheat and rice, may help to improve food security in these areas. The breadfruit is being considered as a substantial staple food with high financial importance (Akanbi et al., 2009).

In the tropics, the plant is used in a variety of food preparations. The pulps of breadfruit are made into various dishes; to produce porridge, it appears to be beaten, seared, bubbled or pounded, it can also be refined into flour and used in the production of bread and cookies (Amusa et al., 2002). It could be used as a fat replacer as per the high dietary value of breadfruit. Despite the importance of breadfruit, its production and use are limited due to lack of knowledge (Omobuwajo, 2003). Thus, there is a need to investigate how to process breadfruit into flour with a dependable capacity which can be utilized to substitute wheat flour in preparing lowfat bakery products. Thus, this research was carried out to incorporate breadfruit flour with wheat flour in the preparation of cookies and to assess the physical, nutritional and sensory properties as affected by incorporation of breadfruit flour in preparation of cookies.

\section{MATERIALS AND METHODS}

\section{Materials}

Good quality, mature breadfruits without any bruises were procured immediately after harvesting from a home garden of a villager from Batticaloa, Sri Lanka. Fruits were washed, wiped to make them free from foreign materials. Cured breadfruits were stored at room temperature and humidity until further use. Other major ingredients such as wheat flour, sugar, baking powder, salt, margarine and vanilla essence were purchased from the local supermarket of Batticaloa.

\section{Preparation of breadfruit flour}

Breadfruits were washed again, peeled and cut into thin slices of 1-mm thickness using a food slicer. The slices were dried in an oven at $105{ }^{\circ} \mathrm{C}$ for 3 hours until the pieces were brittle. The dried chips were milled into flour using an electric food grinder (Model: D17494) and passed through 80 mesh sieve to obtain uniform size flour. The flour was packed in an airtight container and stored under the refrigerated condition at $4^{\circ} \mathrm{C}$ for future use. 
Table 1: Different combinations of composite flours used for the production of cookies

\begin{tabular}{ccc}
\hline Treatment & Breadfruit flour (\%) & Wheat flour (\%) \\
\hline $\mathrm{T}_{1}$ & 00 & 100 \\
$\mathrm{~T}_{2}$ & 20 & 80 \\
$\mathrm{~T}_{3}$ & 40 & 60 \\
$\mathrm{~T}_{4}$ & 60 & 40 \\
$\mathrm{~T}_{5}$ & 80 & 20 \\
$\mathrm{~T}_{6}$ & 100 & 00 \\
\hline
\end{tabular}

\section{Development of cookies from composite flour}

Cookies were developed using the method described by Aderinola and Allikura (2015) with some modifications. The cookie dough was prepared according to the following formula; $100 \mathrm{~g}$ of flour (different proportion of breadfruit flour and wheat flour), sugar (50 g), margarine (50 g), baking powder $(2 \mathrm{~g})$, salt ( $0.5 \mathrm{~g})$, vanilla essence ( 5 $\mathrm{mL}$ ) and various proportion of water to make required consistency. Margarine and ground sugars were creamed in a mixer. Dough that contained flour, water, baking powder, vanilla and salt were added to the cream to obtain a homogeneous mixture. A firm dough was prepared, rolled to $5 \mathrm{~mm}$ thickness in a baking tray and $5 \mathrm{~cm}$ diameter circles were cut with a cookie cutter. The cookies were placed on a greased tray and baked in a pre-heated oven at $200{ }^{\circ} \mathrm{C}$ for 10 minutes. Table 1 shows the different combination of breadfruit and wheat flour used for the production of composite cookies.

\section{Physical parameters of wheat-breadfruit composite flour cookies}

Physical parameters of composite flour cookies such as diameter, volume, breaking strength, spread ratio and thickness were determined. The diameter of cookies was measured in millimetre by Venire calliper. The thickness of cookies was measured using Screw gauge and recorded in millimetres. The volume of cookies was calculated by multiplying the area of a cookie by its thickness. The spread ratio was calculated by dividing the diameter of a cookie by its thickness. The breaking strength was determined according to the method described by Ikuomola et al. (2017). Analyses were carried out using three replicates for each treatment.

\section{Nutritional and sensory analysis of wheat- breadfruit composite flour cookies}

Composite flour blend cookies were analysed for moisture, ash, protein, fat, fibre and soluble carbohydrate contents according to the AOAC (2019) methods. The percentage of antioxidant activity (AA\%) of each treatment was assessed by 2,2-diphenyl-1-picrylhydrazyl (DPPH) free radical assay (Brand-Williams et al., 1995; Thongram et al., 2016). The samples were reacted with the stable DPPH radical in an ethanol solution. The reaction mixture consisted of $0.5 \mathrm{ml}$ of sample, $3 \mathrm{ml}$ of absolute ethanol and $0.3 \mathrm{ml}$ of $0.5 \mathrm{mM}$ DPPH radical solution in ethanol. The changes in colour from deep violet to light yellow were read at $517 \mathrm{~nm}$ after $100 \mathrm{~min}$ of reaction using a UV-VIS spectrophotometer. The blank solution was prepared by mixing $3.5 \mathrm{ml}$ of ethanol with $0.3 \mathrm{ml}$ of DPPH radical solution.

The total phenolic content was determined according to the method described by Makkar et al. (1997) and Thongram et al. (2016). Aliquots of the extract were taken in a test tube and made up to the volume of $1 \mathrm{ml}$ with distilled water. To this, FolinCiocalteu reagent $(0.5 \mathrm{ml})$ and $20 \%$ sodium carbonate solution $(2.5 \mathrm{ml})$ were added sequentially in each tube. Tubes were vortexed and soon after these were placed in dark for $40 \mathrm{~min}$ and the absorbance was recorded at $725 \mathrm{~nm}$ against reagent blank. The amount of total phenolic content was calculated as gallic acid equivalents from a calibration curve. Analyses were carried out using three replicates for each treatment.

Sensory parameters, such as colour, taste, texture, aroma and overall acceptability were evaluated by a panel consisting of 20 trained members using a seven-point hedonic scale. The rating of the samples ranged from 1 (dislike very much) to 7 (like very much). Three-digit number-coded samples and questionnaire were given to panel 
members at a time and they were asked to rate their hedonic response on the scale.

\section{Statistical analysis}

The experiment was carried out in a complete randomized design with six treatments. The significance of the treatment effects on measured parameters were analysed by Analysis of Variance (ANOVA) $(\alpha=0.05)$. The difference between means of physical characteristics and nutritional parameters was determined by Duncan's Multiple Range Test (DMRT) and Tukey's studentized range test for sensory evaluation. Data were analysed using Statistical Analysis System (SAS) software.

\section{RESULTS AND DISCUSSION}

\section{Nutritional composition of wheat- breadfruit flour composite cookies}

Nutritional composition of wheat flour and breadfruit flour is shown in Table 2. Protein, fat and moisture contents were higher in wheat flour than in breadfruit flour. However, ash, fibre and total carbohydrate contents were higher in breadfruit flour than in wheat flour. The nutritional composition of breadfruit flour is in accordance with the results obtained by Appiah et al. (2011) and Ishaya et al. (2013).

The moisture and ash contents of cookies made from blends of wheat-breadfruit composite flour are shown in Table 2. The rate of deterioration of a food product is reflected by moisture content because high moisture content induces the microbial activity as well as enzymatic deterioration. The moisture content of cookies gradually increased from 3.37 to $4.34 \%$ with the addition of breadfruit flour from 0 to $100 \%$. This result was supported by Bakare et al. (2014). The ash content of cookies increased from 2.73 to $3.76 \%$ with the increase of breadfruit flour from 0 to $100 \%$. It might be due to higher ash content present in the breadfruit flour compared to wheat flour (Olaoye and Onilude, 2008). These results are in agreement with the results obtained by Adepeju et al. (2015). Breadfruit flour contained a higher amount of ash content $(2.67 \%)$ compared with the wheat flour $(0.51 \%)$. The ash content of a food material is an indicator of the mineral substances of a specific food item (Sidorova et al., 2007). Therefore, a combination of breadfruit flour in the development of cookies would enhance the mineral intake of consumers.

Table 2: Nutritional value of wheat-breadfruit flour composite cookies

\begin{tabular}{|c|c|c|c|c|c|c|}
\hline Treatments & $\begin{array}{c}\text { Moisture } \\
\text { (\%) }\end{array}$ & $\begin{array}{l}\text { Ash } \\
\text { (\%) }\end{array}$ & $\begin{array}{c}\text { Fibre } \\
\text { (\%) }\end{array}$ & $\begin{array}{c}\text { Protein } \\
\text { (\%) }\end{array}$ & $\begin{array}{l}\text { Fat } \\
(\%)\end{array}$ & $\begin{array}{c}\text { Total } \\
\text { carbohydrate } \\
\text { (\%) }\end{array}$ \\
\hline $\mathbf{T}_{1}$ & $3.37 \pm 0.027^{f}$ & $2.73 \pm 0.023^{f}$ & $0.97 \pm 0.015^{f}$ & $12.46 \pm 0.029 a$ & $20.48 \pm 0.031^{\mathrm{a}}$ & $59.92 \pm 0.024^{f}$ \\
\hline $\mathbf{T}_{2}$ & $3.45 \pm 0.039 \mathrm{e}$ & $2.89 \pm 0.041^{\mathrm{e}}$ & $1.36 \pm 0.027 \mathrm{e}$ & $11.52 \pm 0.018^{b}$ & $19.22 \pm 0.036^{b}$ & $61.54 \pm 0.029 \mathrm{e}$ \\
\hline $\mathbf{T}_{3}$ & $3.53 \pm 0.015^{d}$ & $3.24 \pm 0.037 \mathrm{~d}$ & $1.75 \pm 0.022^{\mathrm{d}}$ & $10.92 \pm 0.021^{c}$ & $18.71 \pm 0.021^{c}$ & $61.73 \pm 0.033^{d}$ \\
\hline $\mathbf{T}_{4}$ & $3.71 \pm 0.021^{\mathrm{c}}$ & $3.35 \pm 0.013^{c}$ & $2.15 \pm 0.015^{c}$ & $10.89 \pm 0.038 \mathrm{bc}$ & $17.01 \pm 0.026^{d}$ & $62.88 \pm 0.065^{c}$ \\
\hline $\mathbf{T}_{\mathbf{5}}$ & $4.16 \pm 0.051^{b}$ & $3.52 \pm 0.029 b$ & $2.95 \pm 0.020^{b}$ & $9.64 \pm 0.021^{d}$ & $15.77 \pm 0.039 \mathrm{e}$ & $63.75 \pm 0.020^{b}$ \\
\hline $\mathbf{T}_{6}$ & $4.34 \pm 0.036^{\mathrm{a}}$ & $3.76 \pm 0.023^{a}$ & $3.02 \pm 0.023^{a}$ & $9.04 \pm 0.020 \mathrm{e}$ & $14.82 \pm 0.026^{f}$ & $64.93 \pm 0.027 a$ \\
\hline Wheat flour & $10.31 \pm 0.13^{\mathrm{A}}$ & $0.51 \pm 0.04^{\mathrm{B}}$ & $0.63 \pm 0.03^{\text {В }}$ & $13.30 \pm 0.34^{\mathrm{A}}$ & $2.30 \pm 0.32^{\mathrm{A}}$ & $72.50 \pm 0.36^{\mathrm{B}}$ \\
\hline $\begin{array}{c}\text { Breadfruit } \\
\text { flour }\end{array}$ & $6.11 \pm 0.13^{\mathrm{B}}$ & $2.67 \pm 0.06^{\mathrm{A}}$ & $3.67 \pm 0.04 \mathrm{~A}$ & $3.45 \pm 0.04^{\mathrm{B}}$ & $1.91 \pm 0.07^{\mathrm{B}}$ & $79.50 \pm 0.51^{\mathrm{A}}$ \\
\hline
\end{tabular}

Note: The values are means of triplicates \pm standard error. Values with the different superscripts in lower case letters in the same column are significantly different at $\mathrm{p}<0.05$, among the different treatments, $\mathrm{T}_{1}-\mathrm{T}_{6}$. $\left(\mathrm{T}_{1}: 100 \%\right.$ wheat flour; $\mathrm{T}_{2}: 80 \%$ wheat flour $20 \%$ breadfruit flour; $\mathrm{T}_{3}: 60 \%$ wheat flour $40 \%$ breadfruit flour; $\mathrm{T}_{4}: 40 \%$ wheat flour $60 \%$ breadfruit flour; $\mathrm{T}_{5}: 20 \%$ wheat flour $80 \%$ breadfruit flour; $\mathrm{T}_{6}: 100 \%$ breadfruit flour). Values with the upper-case letters within the same column are significantly different (Between the two different flour types). 
The fibre content of cookies increased from 0.97 to $3.02 \%$ when increase the breadfruit flour from 0 to $100 \%$ in flour blend used in preparation of cookies. The fibre content of cookies increased significantly $(P<0.05)$ because the breadfruit flour has relatively higher fibre $(3.67 \%)$ compared to wheat flour $(0.63 \%)$. Our results are in agreement with the finding of Mepba et al. (2007). Plant sources have a diversity of fibres. They have been used in the preparation of cookies to improve the texture, colour and aroma (Osturk et al., 2002). The protein content of cookies decreased from 12.46 to $9.04 \%$ with the increase of breadfruit flour from 0 to $100 \%$ (Table 2). These findings were supported by Olaoye et al. (2007). The protein content of wheat $(13.3 \%)$ is higher than the protein content of breadfruit flour (3.45\%) (Udio et al., 2003).

The changes in the fat content of wheat-breadfruit composite flour cookies is presented in Table 2 . The fat content of cookies decreased from 20.48 to $14.82 \%$ with the increase of breadfruit flour from 0 to $100 \%$. These findings were supported by Barber et al. (2016). According to DMRT, the highest fat content $(20.41 \%)$ was recorded for cookies made using $100 \%$ wheat flour while the lowest value (14.71\%) was obtained for those made with $100 \%$ breadfruit flour in the recipe. Fat plays a major role in the timeframe of realistic usability of the food item since fat has the capacity of produce rancidity prompting advancement of unpleasant and unpromising odour (Barber et al., 2016). Total carbohydrate content showed significant increase from 59.92 to $64.93 \%$ with the increasing of breadfruit flour from 0 to $100 \%$. These findings were also supported by Barber et al. (2016). Cookies made of breadfruit-wheat composite flour had a high carbohydrate content. This may be due to the high carbohydrate content in breadfruit flour (79.5\%) than in wheat flour (72.5\%) (Malomo et al., 2011).

Total phenolic content of composite cookies is shown in Figure 1. According to the statistical analysis, the addition of breadfruit flour had a significant effect $(\mathrm{p}<0.05)$ on the total phenolic content of cookies. Total phenolic content of cookies ranged from 12.1 to $44.68 \mathrm{TAE} \mathrm{mg} / 100 \mathrm{~g}$. Total phenolic content increased with the increase of breadfruit flour from 0 to $100 \%$. Breadfruit is considered as one of the richest plant species in phenolic compounds (Robards and Antolovich, 1997). Phenolic compounds prevent cancer, neurodegenerative diseases and cardiovascular diseases (Yao et al., 2004) in humans, as the free radical scavenging activity increases with the increase of phenolic compounds.

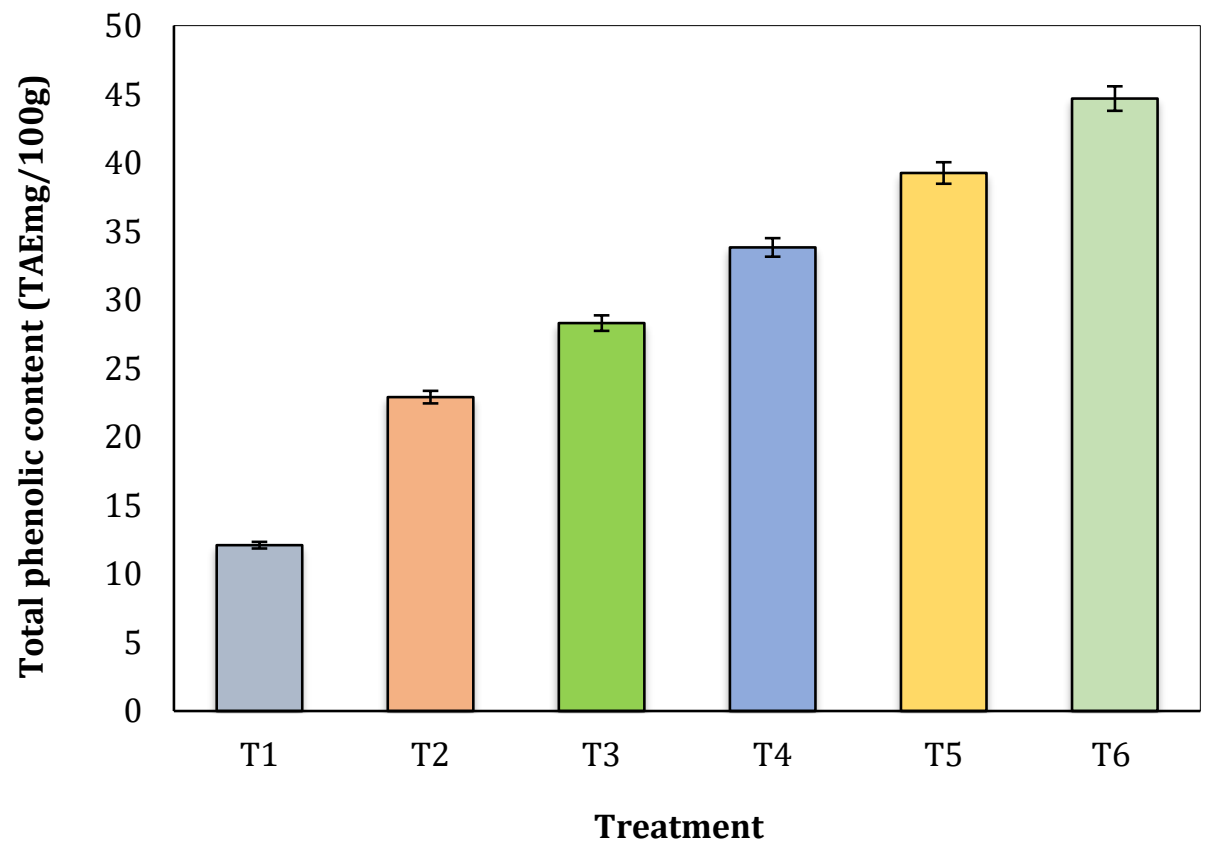

Figure 1: Total phenolic content of wheat-breadfruit composite flour cookies

Note: The values are means of triplicates. Vertical bars indicate the standard errors of means. $\mathrm{T}_{1}: 100 \%$ wheat flour; $\mathrm{T}_{2}: 80 \%$ wheat flour 20\% breadfruit flour; $\mathrm{T}_{3}: 60 \%$ wheat flour $40 \%$ breadfruit flour; $\mathrm{T}_{4}: 40 \%$ wheat flour $60 \%$ breadfruit flour; $\mathrm{T}_{5}: 20 \%$ wheat flour $80 \%$ breadfruit flour; $\mathrm{T}_{6}: 100 \%$ breadfruit flour. 


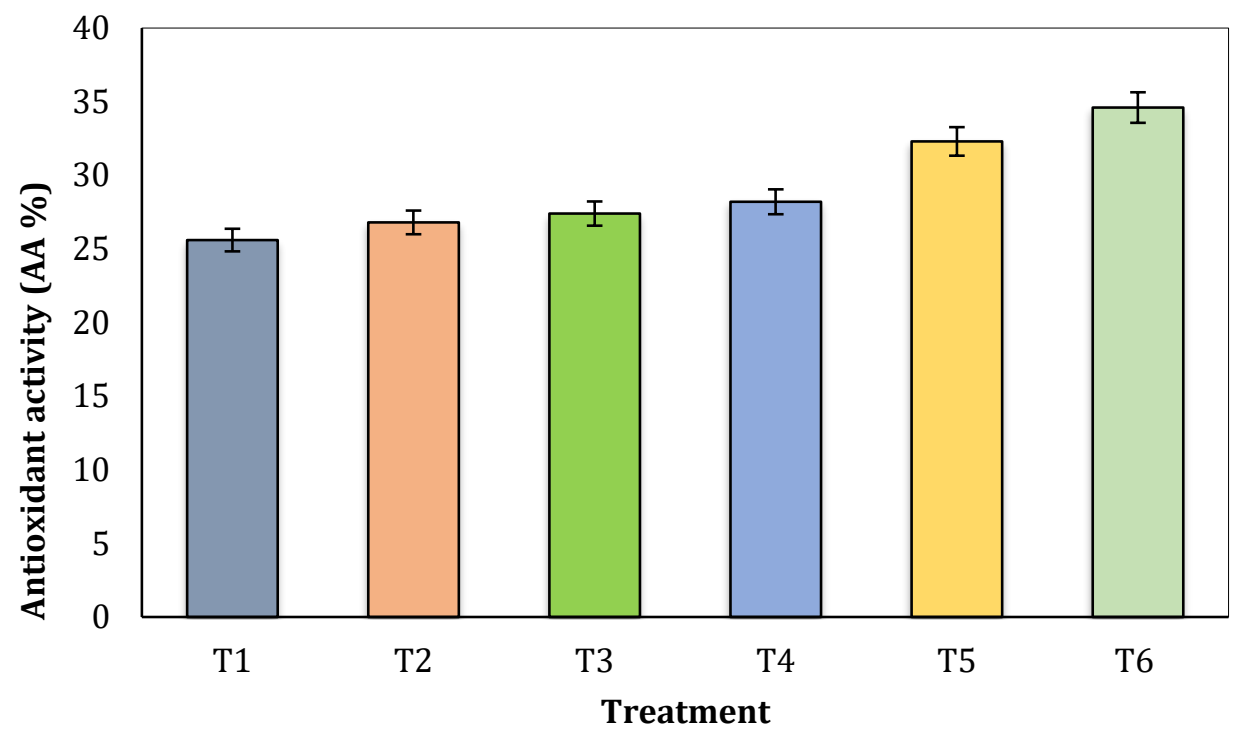

Figure 2: The antioxidant activity of wheat-breadfruit composite flour cookies

Note: The values are means of triplicates. Vertical bars indicate the standard errors of means. $\mathrm{T}_{1}: 100 \%$ wheat flour; $\mathrm{T}_{2}: 80 \%$ wheat flour 20\% breadfruit flour; $\mathrm{T}_{3}: 60 \%$ wheat flour $40 \%$ breadfruit flour; $\mathrm{T}_{4}: 40 \%$ wheat flour $60 \%$ breadfruit flour; $\mathrm{T}_{5}: 20 \%$ wheat flour $80 \%$ breadfruit flour; $\mathrm{T}_{6}: 100 \%$ breadfruit flour.

Antioxidant activity of composite cookies is shown in Figure 2. The antioxidant activity of cookies increased from 25.6 to $34.6 \%$ with the increase of breadfruit flour from 0 to $100 \%$. The results showed that there was a significant difference $(P<0.05)$ between cookies made from 100\% breadfruit flour and $100 \%$ wheat flour. The free radical scavenging activity increases with the addition of breadfruit flour in the wheat flour and the breadfruit flour contains a good amount of antioxidants (Famurewa et al., 2016). The radical scavenging activity of breadfruit is due to its richness in polyphenols, mainly flavonoids (Lana et al., 2013).

\section{Physical characteristics of wheat- breadfruit composite flour cookies}

The physical parameters of the composite cookies such as diameter, thickness, spread ratio, volume and breaking strength revealed that there were significant differences $(P<0.05)$ between the treatments when breadfruit flour was increased from 0 to $100 \%$ in recipe (Table 3 ). The diameter and spread ratio of composite cookies decreased from 7.07 to $6.64 \mathrm{~cm}$ and 7.24 to $6.86 \mathrm{~cm}$, respectively when the breadfruit

Table 3: Physical characteristics of wheat-breadfruit composite flour cookies

\begin{tabular}{cccccc}
\hline Treatments & $\begin{array}{c}\text { Diameter } \\
(\mathbf{c m})\end{array}$ & Spread ratio & $\begin{array}{c}\text { Thickness } \\
(\mathbf{c m})\end{array}$ & $\begin{array}{c}\text { Volume } \\
\left.\mathbf{( c m}^{3}\right)\end{array}$ & $\begin{array}{c}\text { Breaking } \\
\text { Strength }(\mathbf{k g})\end{array}$ \\
\hline $\mathrm{T}_{1}$ & $7.07 \pm 0.037^{\mathrm{a}}$ & $7.24 \pm 0.001^{\mathrm{a}}$ & $0.968 \pm 0.003^{\mathrm{f}}$ & $42.01 \pm 0.43^{\mathrm{a}}$ & $2.34 \pm 0.003^{\mathrm{a}}$ \\
$\mathrm{T}_{2}$ & $7.06 \pm 0.006^{\mathrm{b}}$ & $7.22 \pm 0.001^{\mathrm{ab}}$ & $0.971 \pm 0.003^{\mathrm{e}}$ & $41.83 \pm 0.03^{\mathrm{b}}$ & $2.08 \pm 0.030^{\mathrm{b}}$ \\
$\mathrm{T}_{3}$ & $7.04 \pm 0.001^{\mathrm{c}}$ & $7.21 \pm 0.003^{\mathrm{ab}}$ & $0.973 \pm 0.005^{\mathrm{d}}$ & $39.94 \pm 0.13^{\mathrm{c}}$ & $1.54 \pm 0.003^{\mathrm{c}}$ \\
$\mathrm{T}_{4}$ & $7.02 \pm 0.005^{\mathrm{d}}$ & $7.20 \pm 0.003^{\mathrm{b}}$ & $0.976 \pm 0.002^{\mathrm{c}}$ & $36.53 \pm 0.003^{\mathrm{d}}$ & $1.14 \pm 0.007^{\mathrm{d}}$ \\
$\mathrm{T}_{5}$ & $6.95 \pm 0.003^{\mathrm{e}}$ & $7.16 \pm 0.005^{\mathrm{c}}$ & $0.979 \pm 0.002^{\mathrm{b}}$ & $34.18 \pm 0.10^{\mathrm{e}}$ & $0.92 \pm 0.010^{\mathrm{e}}$ \\
$\mathrm{T}_{6}$ & $6.64 \pm 0.003^{\mathrm{f}}$ & $6.86 \pm 0.003^{\mathrm{d}}$ & $0.981 \pm 0.001^{\mathrm{a}}$ & $32.66 \pm 0.003^{\mathrm{f}}$ & $0.68 \pm 0.023^{\mathrm{f}}$ \\
\hline
\end{tabular}

Note: The values are means of triplicates \pm standard error. Values of the different superscripts in the same column are significantly different at $\mathrm{p}<0.05$. $\mathrm{T}_{1}: 100 \%$ wheat flour; $\mathrm{T}_{2}: 80 \%$ wheat flour $20 \%$ breadfruit flour; $\mathrm{T}_{3}: 60 \%$ wheat flour $40 \%$ breadfruit flour; $\mathrm{T}_{4}: 40 \%$ wheat flour $60 \%$ breadfruit flour; $\mathrm{T}_{5}: 20 \%$ wheat flour $80 \%$ breadfruit flour; $\mathrm{T}_{6}: 100 \%$ breadfruit flour. 
flour increased from 0 to $100 \%$ in recipe. These findings are in accordance with the values reported by Barber et al. (2016).

These differences may be due to the higher solid matter content, fibre content and high water holding capacity of breadfruit flour. The lower spread ratio is better for crispness and acceptability of baked product (Adepeju et al., 2015). Volume and breaking strength of cookies showed gradual decrease while thickness increased with the level of breadfruit flour usage that changed from 0 to $100 \%$. This may be due to the high solid matter content, fibre content and high water holding capacity of breadfruit flour when compared to wheat flour. Break strength is the least weight that caused the breaking of the biscuit using break strength equipment. The finding of breaking strength was supported by Bakare et al. (2014).

\section{Sensory evaluation of wheat-breadfruit flour composite cookies}

Mean values of sensory evaluation of different treatments according to Turkey's Studentized Range Test are shown in Table 4. These values were in accordance with Agu et al. (2007). Colour is one of the primary sensory attributes of food. Attractive colour improves the demand of food. Sometimes colour of cookies may vary from light brown to dark brown. The dark colour may be due to the Maillard reaction between reducing sugar and protein (Dhingra and Jood, 2000). Taste is the primary factor which determines the acceptability and market value of any product. Breadfruit flour added cookie had more caramel taste than others. This might be due to the caramelization of free sugar in breadfruit flour during baking. According to Tukey's test, $\mathrm{T}_{3}$ had the highest mean value of taste compared with other breadfruit flour added cookies. There were no significant differences ( $p>0.05$ ) between $100 \%$ wheat flour added cookies $\left(\mathrm{T}_{1}\right)$ and $40 \%$ breadfruit flour added cookie $\left(\mathrm{T}_{3}\right)$ in taste. Texture also determines the food quality. Texture measures how a food feels in the mouth. According to Tukey's test, there were no significant differences ( $p>0.05)$ between control treatment $\left(\mathrm{T}_{1}\right)$ and $40 \%$ breadfruit flour added cookies.

Aroma also plays an important role as a sensory parameter in determining the acceptability of new food products in the market. According to Tukey's test, there were no significant differences $(P>0.05)$ among treatments. $40 \%$ breadfruit flour added cookies had the highest mean value compared with other breadfruit flour added cookies. Overall acceptability will determine the overall quality of the food product. According to the Tukey's test, $40 \%$ breadfruit flour added cookies (T3) had the highest mean value for overall acceptability among other breadfruit flour added cookies, which was not significantly different from cookies prepared with $100 \%$ wheat flour. $100 \%$ breadfruit flour added cookies had the least overall acceptance. There were no significant differences $(P>0.05)$ between $100 \%$ wheat flour added cookies $\left(\mathrm{T}_{1}\right)$ and $40 \%$ breadfruit flour added cookie $\left(\mathrm{T}_{3}\right)$ with respect to overall acceptance.

Table 4: Sensory parameters of wheat-breadfruit flour composite cookies

\begin{tabular}{cccccc}
\hline Treatments & Colour & Taste & Texture & Aroma & $\begin{array}{c}\text { Overall } \\
\text { Acceptability }\end{array}$ \\
\hline $\mathrm{T}_{1}$ & $5.60 \pm 0.41^{\mathrm{a}}$ & $5.80 \pm 0.47^{\mathrm{a}}$ & $6.20 \pm 0.37^{\mathrm{a}}$ & $5.80 \pm .24^{\mathrm{a}}$ & $5.60 \pm 0.28^{\mathrm{ab}}$ \\
$\mathrm{T}_{2}$ & $5.20 \pm 0.00^{\mathrm{ab}}$ & $5.20 \pm 0.30^{\mathrm{ab}}$ & $4.40 \pm 0.20^{\mathrm{ab}}$ & $5.20 \pm 0.24^{\mathrm{abc}}$ & $5.20 \pm 0.59^{\mathrm{a}}$ \\
$\mathrm{T}_{3}$ & $5.40 \pm 0.55^{\mathrm{ab}}$ & $5.40 \pm 0.01^{\mathrm{ab}}$ & $4.80 \pm 0.22^{\mathrm{ab}}$ & $5.40 \pm 0.14^{\mathrm{ab}}$ & $5.40 \pm 0.27^{\mathrm{a}}$ \\
$\mathrm{T}_{4}$ & $4.20 \pm 0.27^{\mathrm{ab}}$ & $4.80 \pm 0.37^{\mathrm{b}}$ & $3.60 \pm 0.30^{\mathrm{b}}$ & $4.80 \pm 0.46^{\mathrm{abc}}$ & $4.20 \pm 0.12^{\mathrm{ab}}$ \\
$\mathrm{T}_{5}$ & $3.60 \pm 0.37^{\mathrm{ab}}$ & $3.00 \pm 0.27^{\mathrm{b}}$ & $3.60 \pm 0.40^{\mathrm{b}}$ & $3.00 \pm 0.40^{\mathrm{c}}$ & $3.60 \pm 0.34^{\mathrm{b}}$ \\
$\mathrm{T}_{6}$ & $2.60 \pm 0.17^{\mathrm{b}}$ & $3.00 \pm 0.37^{\mathrm{b}}$ & $3.60 \pm 0.20^{\mathrm{b}}$ & $3.00 \pm 0.30^{\mathrm{c}}$ & $2.60 \pm 0.32^{\mathrm{b}}$ \\
\hline
\end{tabular}

Note: Values are means of 20 replicates \pm standard error

The means with the same letters in the same column are not significantly different from each other at $\mathrm{p}<0.05$.

$\mathrm{T}_{1}: 100 \%$ wheat flour; $\mathrm{T}_{2}: 80 \%$ wheat flour $20 \%$ breadfruit flour; $\mathrm{T}_{3}: 60 \%$ wheat flour $40 \%$ breadfruit flour; $\mathrm{T}_{4}: 40 \%$ wheat flour $60 \%$ breadfruit flour; $\mathrm{T}_{5}: 20 \%$ wheat flour $80 \%$ breadfruit flour; $\mathrm{T}_{6}: 100 \%$ breadfruit flour 


\section{CONCLUSIONS}

The present study was carried out as an effort to formulate value-added cookies with breadfruit flour in terms of increasing crude fibre and mineral contents while reducing fat content. The breadfruit flour was high in fibre and mineral contents while having a low fat content. Incorporating breadfruit flour in the recipe improved mineral, carbohydrate

\section{REFERENCES}

Adepeju, A.B., Abidun, O.A., Otutu, O.L. and Pele, J.G. (2015). Development and quality evaluation of wheat/breadfruit cookies. International Journal of Technical Research and Applications. 3(6), 7-11. DOI: 10.12691/jfnr-4-10-5.

Aderinola, T.A. and Allikura, O.J. (2015). Quality evaluation of cookies made from wheat and breadfruit composite flour. Annals. Food Science and Technology. 16(2), 354-358.

Agu, H.O., Ayo, J.A., Paul, A.M. and Folorunsho, F. (2007). Quality characteristics of biscuits made from wheat and African breadfruit. Nigerian Food Journal. 25, 19-27. DOI: 10.4314/ nifoj.v25i2

Akanbi, T.O., Nazamid, S. and Adebowale, A.A. (2009). Functional and pasting properties of tropical breadfruit (Artocarpus altilis) starch from Ile-Ife, Osun State, Nigeria. International Food Research Journal. 16, 151-157.

Akubor, P.I, Isolokwu, P.C., Ugbane, O. and Onimawo, I.A. (2000). Proximate composition and functional properties of African breadfruit Kernel and wheat flour blends. Food Research International. 33, 707-712. https://doi.org/ 10.1016/S0963-9969 (00)00116-2

Amusa, N.A., Kehinde, I.A. and Ashange, O.A. (2002). Biodeterioration of breadfruit (Artocarpus cummunis) in storage and its effects on the nutrient composition. African Journal of Biotechnology. 1(2), 57-60. DOI: 10.5897/AJB2002.000-010

AOAC. (2019). Official Methods of Analysis. (21 $1^{\text {st }}$ Edition). Association of Official Analytical Chemists. Washington, USA.

Appiah, F., Oduro, I. and Ellis, W.O. (2011). Proximate and mineral composition of Artocarpus altilis pulp flour as affected by fermentation. Pakistan Journal of Nutrition. 10(7), 653-657. DOI: 10.3923/pjn. 2011 .653 .657 and fibre contents of the cookies while it decreasing the fat and protein contents. Based on the physical, nutritional and sensory qualities, $40 \%$ breadfruit flour and $60 \%$ wheat flour added cookies $\left(\mathrm{T}_{3}\right)$ were highly acceptable similar to $100 \%$ wheat flour cookies. The utilization of breadfruit in food products will go a long way in enhancing its usage and thus, preventing wastage of this valuable fruit.

Arshad, M.U., Anjum, F.M., and Zahoor, T. (2007). Nutritional assessment of cookies supplemented with defatted wheat germ. Food Chemistry. 102, 123-128. DOI: 10.1016/j.foodchem.

Bakare, A.H., Adegunwa, M.O., Akinribido, O.M. and Obadina, O.A. (2014). Proximate, baking, and sensory qualities of biscuits from wheat and fermented breadfruit (Artocarpus communis Frost) flour. Journal of Culinary Science and Technology. 12(4), 316-325. https://doi.org/ $10.1080 / 15428052.2014 .904833$

Barber, L.I., Emelike, N.J.T. and Sunday, B.N. (2016). Utilization of breadfruit in low-fat cookie formulation. Journal of Food and Nutrition Research. 4(10), 658-663. DOI: 10.12691/jfnr4-10-5

Brand-Williams, W., Cuvelier, M.E. and Berset, C. (1995). Use of a free radical method to evaluate antioxidant activity. Lebenson Wiss Technology. 28, 25-30.

Dingara, S. and Jood, S. (2000). Organoleptic and nutrition evaluation of wheat bread supplemented with coconut flour and barley flour. Food Chemistry. 77, 479-488.

Drewnowski, A., Nordenten, K. and Dwyer, J. (1998). Replacing sugar and fat in cookies: impact on product quality and preference. Food Quality and Preference. 9(1-2), 13-20. DOI: $10.12691 /$ jfnr-4-10-5

Ebere, C.O., Emelike, N.J.T. and Kiin-Kabari, D.B. (2015). Physicochemical and sensory properties of cookies prepared from wheat flour and cashew-apple residue as a source of fibre. Asia Journal of Agriculture and Food Science. 3(2), 213-218.

Emelike, N.J.T., Uwa, F.O., Ebere, C.O. and KiinKabari, D.B. (2015). Effect of drying methods on the physicochemical and sensory properties of cookies fortified with Moringa (Moringa oleifera) leaves. Asian Journal of Agriculture and Food Sciences. 3(4), 361-367. 
Famurewa, J.A.V., Pele, G.I., Esan, Y.O. and Jeremiah, B.P. (2016). Influence of maturity and drying methods on the chemical, functional and antioxidant properties of breadfruit (Artocarpus altilis). Biotechnology Journal International. 16(1), 1-9. DOI: 10.9734/BBJ/ $2016 / 25535$

Honda, S. and Jood, S. (2005). Organoleptic and nutritional evaluation of wheat biscuits supplemented with untreated and treated fenugreek flour. Food Chemistry. 90, 427-435. http://dx.doi.org/10.1016/j.foodchem

Ikuomola, D.S., Otutu, O.L. and Oluniran, D.D. (2017). Quality assessment of cookies produced from wheat flour and malted barley (Hordeum vulgare) bran blends. Cogent Food and Agriculture. 3, 1-12.

Ishaya, F.A. and Oshodi, A.A. (2013). The proximate composition and sensory evaluation of the flours of breadfruit (Artocarpus altilis), Benth Seed (Adenopus breviflorus) and their composite bread. Chemistry and Materials Research. 3(9), 79-83.

Kiin-Kabari, D.B. and Giami, S.Y. (2015). Physicochemical properties and in-vitro protein digestibility of non-wheat cookies prepared from Plantain flour and Bambara Groundnut Protein concentrate. Journal of Food Research. 4(20), 78-86. DOI: $10.5539 /$ jfr.v4n2p78

Makkar, H.P.S., Becker, K., Abel, H. and Pawelzik, E. (1997). Nutrient contents, rumen protein degradability and antinutritional factors in some colour and white-flowering cultivars of Vicia faba beans. Journal of the Science of Food and Agriculture. 75, 511-520. https://doi.org/ 10.1002/(SICI)1097-0010(199712)75:4< 511 ::AID-JSFA907>3.0.CO;2-M

Malomo, S.A., Eleyinmi, A.F. and Fashakin, J.B. (2011). Chemical composition, rheological properties and bread-making potentials of composite flours from breadfruit, breadnut and wheat. African Journal of Food Science. 5(7), 400-410. https://doi.org/10.5897/AJFS. 9000 048

Mepba, H.D., Eboh, L. and Nwaojigwa, S.U. (2007). Chemical composition, functional and baking properties of wheat-plantain composite flours. African Journal of Food, Agriculture, Nutrition and Development. 7(1), 1-21. DOI:10.4314/ ajfand.v7i1
Olaoye, O.A. and Onilude, A.A. (2008). Microbiological, proximate analysis and sensory evaluation of baked product from blends of wheat-breadfruit flours. African Journal of Food, Agriculture, Nutrition and Development. 8(2), 192-203.

Olaye, O.A, Onilude, A.A. and Oladoye, C.O. (2007). Breadfruit flour in biscuit making: Effects on product quality. African Journal of Food Science. 1, 20-23.

Omobuwajo, T.O. (2003). Compositional characteristics and sensory quality of biscuit, prawn crackers and fried chips. Journal of Innovative Food Science and Emerging Technologies. 4(2), 219-225. DOI: 10.1016/ S1466-8564(03)00006-7

Ozturk, S., Ozboy, O., Cavidoglu, I. and Koksel, H. (2002). Effects of brewers spent grain on the quality and dietary fibre content of cookies. Journal of the Institute of Brewing. 108, 23-27. https://doi.org/10.1002/j.2050-0416.2002. tb00116.x

Ragone, D. (2006). Artocarpus altilis (breadfruit). In: Elevitch, C.R. (Ed). Traditional Trees of Pacific Islands, Permanent Agriculture Resources, Holualoa, Hawaii. pp. 85-100..

Robards, K. and Antolovich, M. (1997). Analytical chemistry of fruit bioflavonoids A Review. Analyst. 122, 11-34.

Sidorova, L.N., Baľkov, V.G., Bessonov, V.V. and Skobel'skaia, Z.G. (2007). Effect of dietary fibres on the preservation of lipid component in flour confectionery. Voprosy Pitaniia. 76(3), 78-81.

Suriya, M., Reshu, R., Chagam, K.R., Sundaramoorthy, H. and Mudasir, B. (2017). Functional and physicochemical characteristics of cookies prepared from Amorphophallus paeoniifolius flour. Journal of Food Science and Technology. 54(7), 2156-2165. DOI: 10.1007/ s13197-017-2656-y

Thongram, S., Tanwar, B., Chauhan, A. and Kumar, V. (2016). Physicochemical and organoleptic properties of cookies incorporated with legume flours. Cogent Food and Agriculture. 2, 1-12. https://doi.org/10.1080/23311932.2016.117 2389

Udio, A.J., Osuntogun, B.A., Falade, M.O. and Adewusi, S.A. (2003). Chemical analysis of breadfruit (Artocarpus communis Forst) from 
southern western. Nigerian Journal of Food Technology. 1(2), 29-35.

Wang, X., Chen, L., Li, X., Xie, F., Liu, H. and Yu, L. (2011). Thermal and rheological properties of breadfruit starch. Journal of Food Science. 76(1), 55-61.
Yao, L.H., Jiang, Y.M., Shi, J., Tomàs-Barberàs, F.A., Datta, N., Singanusong, R. and Chen S.S. (2004). Flavonoids in food and their health benefits. Plant Foods for Human Nutrition. 59(3), 113122. DOI: $10.1007 / \mathrm{s} 11130-004-0049-7$

Zerega, N.J., Ragone, D. and Motley, T.J. (2005). Systematics and species limits of breadfruit (Artocarpus, Moraceae). Systematic Botany. 30(3), 603-615. 